\title{
Neurochemical and Behavioral Alterations in Glucocorticoid Receptor-Impaired Transgenic Mice after Chronic Mild Stress
}

\author{
Nicolas Froger, ${ }^{1}$ Enza Palazzo, ${ }^{1}$ Claudette Boni, ${ }^{1}$ Naïma Hanoun, ${ }^{1}$ Françoise Saurini, ${ }^{1}$ Chantal Joubert, ${ }^{2}$ \\ Isabelle Dutriez-Casteloot, ${ }^{3}$ Michaela Enache, ${ }^{3}$ Stefania Maccari, ${ }^{4}$ Nicholas Barden, ${ }^{5}$ Charles Cohen-Salmon, ${ }^{2}$ \\ Michel Hamon, ${ }^{1}$ and Laurence Lanfumey ${ }^{1}$ \\ ${ }^{1}$ Institut National de la Santé et de la Recherche Médicale U288 -Neuropsychopharmacologie and ${ }^{2}$ Unité Mixte de Recherche 7593-Centre National de la \\ Recherche Scientifique-Personnalités et Conduites Adaptatives, Institut Fédératif de Recherche 70 des Neurosciences, Centre Hospitalier Universitaire \\ Pitié-Salpêtrière, 75013 Paris, France, ${ }^{3}$ Neuroendocrinologie du Développement, UPRES-EA 2701, and ${ }^{4}$ Stress Périnatal, UPRES-JE 2395, Université de Lille \\ 1, 59655 Villeneuve d'Ascq, France, and ${ }^{5}$ Laval University Hospital Research Centre and Department of Anatomy and Physiology, University Laval, Ste Foy, \\ Quebec G1V 4G2, Canada
}

Mice (GR-i) bearing a transgene encoding a glucocorticoid receptor (GR) antisense RNA under the control of a neuron-specific neurofilament promoter were used to investigate the effects of a 4 week chronic mild stress (CMS) on the hypothalamo-pituitary-adrenocortical (HPA) axis and the serotoninergic system in a transgenic model of vulnerability to affective disorders. GR-i mice showed a decrease in both GR-specific binding (hippocampus and cerebral cortex) and GR mRNA levels [hippocampus, cerebral cortex, and dorsal raphe nucleus (DRN)] as well as a deficit in HPA axis feedback control (dexamethasone test) compared with paired wild-type (WT) mice. In the latter animals, CMS exposure caused a significant decrease in both GR mRNA levels and the density of cytosolic GR binding sites in the hippocampus, whereas, in the DRN, GR mRNA levels tended to increase. In contrast, in stressed GR-i mice, both GR mRNA levels and the density of GR binding sites were significantly increased in the hippocampus, cerebral cortex, and DRN. Electrophysiological recordings in brainstem slices and $\left[\gamma_{-}{ }^{35} \mathrm{~S}\right] \mathrm{GTP}-\mathrm{S}$ binding measurements to assess $5-\mathrm{HT}_{1 \mathrm{~A}}$ receptor functioning showed that CMS exposure produced a desensitization of DRN 5-HT $1 \mathrm{~A}$ autoreceptors in WT, but not in GR-i, mice. In addition, CMS was found to facilitate choice behavior of WT, but not GR-i, mice in a decision-making task derived from an alternation paradigm. These results demonstrate that impaired GR functioning affects normal adaptive responses of the HPA axis and 5-HT system to CMS and alters stress-related consequences on decision-making behaviors.

Key words: 5- $\mathrm{HT}_{1 \mathrm{~A}}$ receptors; glucocorticoid receptors; dorsal raphe nucleus; transgenic mice; chronic mild stress; major depressive disorders

\section{Introduction}

Vulnerability to major affective disorders, particularly depression that is associated with hyperactivity of the hypothalamopituitary-adrenocortical (HPA) axis and hypoactivity of the serotoninergic (5-HT) system, has been shown to involve both genetic and environmental factors (Cadoret et al., 1985, 1996; Kendler et al., 2002). HPA axis activity is controlled by a feedback mechanism triggered mainly through the stimulation of glu-

Received Sept. 8, 2003; revised Dec. 29, 2003; accepted Jan. 17, 2004

This work was supported by the Institut National de la Santé et de la Recherche Médicale, Bristol-Myers Squibb Foundation (Unrestricted Biomedical Research Grant Program), and the European Community (FP6, 2003). N.F. was the recipient of a fellowship from the Ministère de l'Education Nationale et de la Recherche (France) during the performance of this work. We are grateful to the pharmaceutical companies Troponwerke-Bayer and Wyeth-Ayerst for the generous gifts of drugs.

Correspondence should be addressed to Dr. Nicolas Froger, Institut National de la Santé et de la Recherche Médicale U288, Neuropsychopharmacologie Moléculaire, Cellulaire et Fonctionnelle, Faculté de Médecine PitiéSalpêtrière, 91, Boulevard de l'Hôpital, 75634 Paris Cedex 13, France. E-mail: nifroger@ext.jussieu.fr.

DOI:10.1523/JNEUROSCI.4132-03.2004

Copyright $\odot 2004$ Society for Neuroscience $\quad$ 0270-6474/04/242787-10\$15.00/0 cocorticoid receptors (GRs) located in the cerebral cortex, the hippocampus, and the hypothalamus (Magarinos et al., 1987; Dorio et al., 1993; Feldman and Weidenfeld, 1999; Mizoguchi et al., 2003), and a reduced GR expression and function has been proposed to contribute to HPA axis alterations in depression (Holsboer and Barden, 1996; Pariante and Miller, 2001; Webster et al., 2002). In line with this hypothesis, GR activation by acute administration of dexamethasone to trigger the negative feedback mechanism markedly suppresses ACTH and cortisol secretion normally induced by corticotropin-releasing hormone in control healthy subjects but not in depressed patients (Carrol et al., 1981). Depression-associated deficit in HPA axis regulation might be related to the decreased serotoninergic neurotransmission evidenced in depressed patients (Arango et al., 2001), because GR expression is actually dependent on the central 5-HT tone (Barden, 1999; Héry et al., 2000).

A mouse model of impaired GR (GR-i) function has been produced by insertion into the genome of a transgene expressing constitutively GR antisense RNA under the control of a neuron- 
specific neurofilament promoter (Pepin et al., 1992). GR-i mice showed reduced GR mRNA levels $(\sim-50$ to $-70 \%)$ predominantly in brain (Pepin et al., 1992) and reduced HPA axis response to glucocorticoids (Stec et al., 1994; Barden, 1999). As a result of GR-i function, HPA axis regulation is highly disturbed, and these animals have been proposed to be a transgenic model for depression (Holsboer and Barden, 1996). Indeed, several studies showed that most chronic stress procedures lead to a downregulation of GR in both the hippocampus and hypothalamus and induce a prolonged hyperactivity of the HPA axis because of failure in negative feedback normally exerted through these receptors (Johren et al., 1994; Makino et al., 1995; Kitraki et al., 1999; Mizoguchi et al., 2001). Interestingly, chronic mild stress (CMS) conditions also produce long-term changes in behavior and central 5-HT neurotransmission (Lanfumey et al., 1999; Pardon et al., 2000), which can be reversed by antidepressant drugs (Muscat et al., 1992; Willner, 1997), indicating that rodents subjected to such conditions can also be considered as a model for depression.

Accordingly, both this genetic GR-i model and the stress model seemed to us as being especially relevant to investigate some of the neurobiological mechanisms associated with interactions between genetic and environmental factors causing depression. GR-i mice were, thus, subjected to CMS to combine both genetic and environmental factors in the same animals, and appropriate electrophysiological, biochemical, and behavioral approaches were used to investigate the resulting changes in HPA axis activity, 5-HT neurotransmission, and operant behavior.

\section{Materials and Methods}

Animals

Transgenic mice (strain B6C3F1; line 1.3) (Pepin et al., 1992), heterozygous for the presence of the transgene expressing rat GR antisense RNA, were mated together. Mice homozygous for the presence of the transgene (GR-i) or for its absence [wild-type (WT)] were bred at Institut National de la Santé et de la Recherche Médicale unit 288 animal facility. Males and females were separated at weaning and housed six per cage under standard conditions ( $12 \mathrm{hr}$ light/dark cycle; lights on at 7:00 A.M.; $22 \pm 1^{\circ} \mathrm{C}$ ambient temperature; $60 \%$ relative humidity; food and water ad libitum). Experiments were performed using 10- to 12-week-old mice (25-30 gm body weight).

Procedures involving animals and their care were conducted in conformity with the institutional guidelines that are in compliance with national and international laws and policies (Council directive 87-848, October 19, 1987, Ministère de l'Agriculture et de la Forêt, Service Vétérinaire de la Santé et de la Protection Animale; permissions 75-116 to M.H. and 006269 to L.L.).

\section{Genotyping}

Mouse genotype was determined by PCR analysis. Two sets of primers were used: one for the transgene, a 21 mer forward oligonucleotide corresponding to the human neurofilament promoter (Pepin et al., 1992) and a 22 mer reverse oligonucleotide corresponding to the rat GR transgene (5'-CTAGGGTGTCAAAAGGGAGCA-3' and $5^{\prime}$-CTGCAAACCGGTCAGATGAAAG- $3^{\prime}$, respectively), and a second for the mouse NK1 (substance $\mathrm{P}$ ) receptor gene as a control, a 21 mer forward and a 22 mer reverse oligonucleotide (5'-CTGTGGACTCTGATCTCTTCC-3' and 5' ${ }^{\prime}$-ACAGCTGTCATGGAGTAGATAC-3', respectively).

Mouse tail DNA $(\sim 0.5 \mu \mathrm{g})$ was annealed at $60^{\circ} \mathrm{C}$ and amplified at $72^{\circ} \mathrm{C}$ for 35 cycles in the presence of $430 \mathrm{~nm}$ of each specific primer described above, $2 \mathrm{~mm} \mathrm{MgCl}, 0.2 \mathrm{~mm}$ of each deoxynucleotide triphosphate (dA-, dT-, dG- and dC-TP), 6 mM Tris-HCl, pH 8.8, $16 \mathrm{~mm}$ $\left(\mathrm{NH}_{4}\right)_{2} \mathrm{SO}_{4}, 0.01 \%(\mathrm{v} / \mathrm{v})$ Tween 20 , and $1 \mathrm{U}$ of Eurobiotaq polymerase (Eurobio, Les Ulis, France). The PCR products were analyzed by electrophoresis in a $2 \%$ agarose gel stained with ethidium bromide. The specific amplified sequences were 550 and $360 \mathrm{bp}$ long for the transgene and the control gene, respectively.

\section{Stress procedure}

Experiments on the effects of stress in rodents generally used males as subjects. However, it has been shown that female rats are more vulnerable to stressors than males (Kennett et al., 1986), and depression, possibly triggered by repeated stress, is more frequent in women (Breslau et al., 1995). These observations led us to use female mice in our studies.

The stress procedure was an adaptation for mice of the CMS described by Willner et al. (1987) and Moreau et al. (1992) for the rat. The regimen consisted of a variety of unpredictable mild stressors such as repeated periods of $30^{\circ}$ cage tilt, confinement to small cages $(11 \times 8 \times 8 \mathrm{~cm})$, two $2 \mathrm{hr}$ periods of paired housing, one overnight period of difficult access to food (without any reduction in the actual food ration), one period of continuous overnight illumination, and one overnight period in a soiled cage (50 $\mathrm{ml}$ of water/l of sawdust bedding). Animals were also placed on a reversed light/dark cycle from Friday evening to Monday morning. These stressors were scheduled over a 1 week period and repeated throughout the 4 week experiment. In contrast to previous procedures in the rat, nociceptive stressors and food and water deprivation were excluded, and only environmental and social disturbances were applied (Pardon et al., 2000).

\section{Corticosterone measurement}

Basal levels. Stressed mice were decapitated between 9:00 and 10:00 A.M. on the day immediately after the 4 week CMS session, and control unstressed mice were killed in parallel, under the very same conditions. Blood from trunk vessels was collected in chilled tubes, and serum corticosterone was radioimmunoassayed using an ICN kit (ICN Pharmaceuticals, Orsay, France).

Dexamethasone suppression test. Mice received injections at 9:00 A.M. with either dexamethasone ( $2 \mu \mathrm{g} / 100 \mathrm{gm}$ body weight, i.p.) or its vehicle (saline supplemented with $0.5 \%$ ethanol v/v; $1 \mathrm{ml} / 100$ gm body weight, i.p.) and were decapitated $1 \mathrm{hr}$ later. Serum corticosterone levels were determined using the ICN RIA kit.

\section{$\left[{ }^{3} \mathrm{H}\right]$ Corticosterone binding to GRs and mineralocorticoid receptors}

Mice were decapitated, and brains were removed rapidly and frozen in isopentane chilled at $-30^{\circ} \mathrm{C}$ with dry ice, then stored at $-80^{\circ} \mathrm{C}$. Mineralocorticoid receptor (MR) and GR binding sites were quantified in the cytosol of brain tissues following a procedure adapted from DutriezCasteloot et al. (1999). Assays were performed on pooled extracts from two (cerebral cortex) or three (hippocampus) mice of the same experimental group. In brief, tissues were homogenized in $2.0 \mathrm{ml}$ of ice-cold TEDGM buffer [ $30 \mathrm{~mm}$ Tris, $1 \mathrm{~mm}$ EDTA, $10 \mathrm{~mm}$ sodium molybdate, 1 mM dithiotreitol (DTT), and 10\% glycerol, $\mathrm{pH} 7.4$ ], and homogenates were centrifuged at $120,000 \times g$ for $35 \mathrm{~min}$ at $4^{\circ} \mathrm{C}$ using a $\mathrm{L} 7$ ultracentrifuge (Beckman, Fullerton, CA). The cytosolic fraction was obtained by passing the supernatant $(1.2 \mathrm{ml})$ twice through a Sephadex LH-20 column ( $5 \mathrm{~mm}$ in diameter $\times 40 \mathrm{~mm}$ high) equilibrated with buffer (in mM: 10 Tris, 2 EDTA, 10 sodium molybdate, and $2.3 \beta$-mercaptoethanol, $\mathrm{pH}$ 7.4]. For the determination of MR binding sites, aliquots of cytosol (140 $\mu \mathrm{l})$ were incubated with $\left[{ }^{3} \mathrm{H}\right]$ corticosterone $\left.(79 \mathrm{Ci} / \mathrm{mmol}]\right)$ at $0.63,1.25$, 5 , and $20 \mathrm{~nm}$ in the presence of a 100-fold excess of the specific GR antagonist mifepristone to saturate GR binding sites. Nonspecific binding was determined in the presence of a 500 -fold excess of corticosterone. Specific binding onto GR was quantified by subtracting $\left[{ }^{3} \mathrm{H}\right]$ corticosterone binding to $\mathrm{MR}$ (in the presence of mifepristone) from total specific $\left[{ }^{3} \mathrm{H}\right]$ corticosterone binding. All samples were incubated for $22 \mathrm{hr}$ at $4^{\circ} \mathrm{C}$ to allow $\left[{ }^{3} \mathrm{H}\right]$ corticosterone binding equilibrium. Separation of bound from free $\left[{ }^{3} \mathrm{H}\right]$ corticosterone was performed at $4^{\circ} \mathrm{C}$ using Sephadex LH-20 columns ( $5 \mathrm{~mm}$ in diameter $\times 80 \mathrm{~mm}$ high) preequilibrated with TEDGM buffer, pH 7.4. Under such assay conditions, nonspecific binding corresponded to $20-30 \%$ of total $\left[{ }^{3} \mathrm{H}\right]$ corticosterone binding. Protein concentration in the cytosol was determined by the method of Lowry et al. (1951), with BSA as standard. $B_{\max }$ and $K_{\mathrm{d}}$ values were calculated from Scatchard plots using the program Ligand (McPherson, 1985). 


\section{GR $m R N A$ in situ hybridization}

Probe construction and labeling. A 393 bp GR mouse sequence localized between nucleotides 337 and 730 of the coding region (Danielsen et al., 1986) was amplified by reverse transcription-PCR from cortex total mRNA and subcloned in a TOPO-PCRII vector (In Vitrogen, Carlsbad, CA). Insert orientation was determined by sequencing. The recombinant plasmid was linearized with HindIII, and the antisense RNA probe was synthesized from T7 RNA polymerase promoter, in the presence of 200 $\mu \mathrm{Ci}$ of $\left[{ }^{35} \mathrm{~S}\right] \mathrm{UTP}(1000 \mathrm{Ci} / \mathrm{mmole})$, according to AmpliScribe T7 Amplification kit instructions (Epicenter Technologies, Madison, WI). The labeled probe was then purified using a mini Quick Spin RNA column (Boehringer Mannheim, Meylan, France), and its specific radioactivity was measured with a beta-counter (Beckman).

In situ hybridization. Mice were decapitated between 9:00 and 10:00 A.M. on the day immediately after the 4 week CMS session, and their brains were removed rapidly and frozen in isopentane chilled at $-30^{\circ} \mathrm{C}$ with dry ice, then stored at $-80^{\circ} \mathrm{C}$ until further processing. Coronal sections $\left(20 \mu \mathrm{m}\right.$ thick) were cut at $-20^{\circ} \mathrm{C}$ and thaw mounted onto gelatin-coated slides to be stored at $-80^{\circ} \mathrm{C}$ until use.

Sections were first fixed with $4 \%$ paraformaldehyde in PBS (in mм: $150 \mathrm{NaCl}, 2.5 \mathrm{KCl}, 1.5 \mathrm{KH}_{2} \mathrm{PO}_{4}$, and $8 \mathrm{Na}_{2} \mathrm{HPO}_{4}$, $\mathrm{pH} 7.4$ ) for $30 \mathrm{~min}$ at room temperature; rinsed successively in PBS, distilled water, and TEA $(0.1 \mathrm{M} ; \mathrm{pH} 8.0)$; and acetylated in the presence of $0.25 \%$ acetic anhydride in $0.1 \mathrm{M}$ TEA for $10 \mathrm{~min}$ at room temperature. Sections were then rinsed twice in $2 \times$ SSC, dehydrated through a graded series of ethanol concentrations (50-100\%), and subsequently incubated overnight at $58^{\circ} \mathrm{C}$ in a solution containing $50 \%$ formamide, $300 \mathrm{~mm} \mathrm{NaCl}, 100 \mathrm{~mm}$ Tris- $\mathrm{HCl}$, pH 8.0, 1 mm EDTA, $1 \times$ Denhardt's, $10 \%$ dextran sulfate, $500 \mu \mathrm{g} / \mathrm{ml}$ yeast t-RNA, $10 \mathrm{~mm} \mathrm{DTT}$, and $10^{6} \mathrm{dpm} / \mathrm{ml}$ of $\left[{ }^{35} \mathrm{~S}\right.$ ] labeled RNA probe. After rinsing ( $4 \times$ SSC plus $0.1 \mathrm{~m}$ DTT for $5 \mathrm{~min}$ at room temperature), they were treated with RNase $(200 \mu \mathrm{g} / \mathrm{ml})$ in $10 \mathrm{~mm}$ Tris- $\mathrm{HCl}, \mathrm{pH} 8.0$, supplemented with $500 \mathrm{~mm} \mathrm{NaCl}$ and $1 \mathrm{~mm}$ EDTA, and rinsed successively with solutions of $2 \times, 1 \times$, and $0.5 \times$ SSC, containing $0.1 \mathrm{~mm}$ DTT. Sections were finally dehydrated through a graded series of ethanol concentrations $(50-100 \%)$. Glass slides with sections on were dried by air flow overnight and exposed to a $\beta$-max film (Amersham Pharmacia Biotech, Buckinghamshire, UK). OD was measured on autoradiographic films using a computerized image analysis system (Biocom, Les Ulis, France). The hybridization signal was analyzed at the hippocampus (CA1 area of Ammon's horn), cerebral cortex (at the same anteriority levels as hippocampus: -1.22 to $-2.30 \mathrm{~mm}$ from bregma), and dorsal raphe nucleus (DRN) levels according to the atlas of Franklin and Paxinos (1997). Analyses were performed on six to eight sections per animal at each level.

\section{Quantitative autoradiography of 5-HT $\mathrm{T}_{1 \mathrm{~A}}$ receptor-mediated $\left[\gamma-{ }^{35} S\right] G T P-S$ binding}

Mice were decapitated, and their brains were removed rapidly, frozen in isopentane chilled at $-30^{\circ} \mathrm{C}$ with dry ice, and stored at $-80^{\circ} \mathrm{C}$. Coronal sections $\left(20 \mu \mathrm{m}\right.$ thick) were cut at $-20^{\circ} \mathrm{C}$, thaw mounted onto gelatincoated slides, and then stored at $-80^{\circ} \mathrm{C}$ until use.

The protocol for autoradiographic measurement of 5- $\mathrm{HT}_{1 \mathrm{~A}}$ receptormediated $\left[{ }^{35} \mathrm{~S}\right] \mathrm{GTP}-\gamma-\mathrm{S}$ binding in the DRN and the CA1 area of the hippocampus was adapted from Fabre et al. (2000). Briefly, brain sections were preincubated at room temperature for an initial $15 \mathrm{~min}$ period in $50 \mathrm{~mm}$ HEPES, pH 7.5, supplemented with $100 \mathrm{~mm} \mathrm{NaCl}, 3 \mathrm{~mm} \mathrm{MgCl}$, $0.2 \mathrm{~mm}$ EGTA, and $2 \mathrm{~mm}$ DTT and then for another $15 \mathrm{~min}$ in the same buffer with $2 \mathrm{~mm}$ GDP and $10 \mu \mathrm{M}$ 8-cyclopentyl-1,3-dipropylxanthine (DPCPX; an $\mathrm{A}_{1}$ adenosine receptor antagonist) to decrease background labeling (Fabre et al., 2000). Thereafter, sections were incubated for $1 \mathrm{hr}$ at $30^{\circ} \mathrm{C}$ in the same buffer with $0.05 \mathrm{~nm}\left[{ }^{35} \mathrm{~S}\right] \mathrm{GTP}-\gamma-\mathrm{S}(1000 \mathrm{Ci} / \mathrm{mmol})$ either in the absence (basal conditions) or in the presence (stimulated conditions) of $10 \mu \mathrm{M}$ 5-carboxamido-tryptamine (5-CT). Nonspecific binding was determined in the presence of $10 \mu \mathrm{M}$ WAY 100635 to block $5-\mathrm{HT}_{1 \mathrm{~A}}$ receptors (Fletcher et al., 1996). The incubation was stopped by two 2 min washes in ice-cold 50 mM HEPES, pH 7.5, and a brief immersion in ice-cold distilled water. Sections were dried by air flow and exposed to a $\beta$-max film. OD was measured on autoradiographic films, using a computerized image analysis system (Biocom). 5-CT-stimulated $\left[{ }^{35} \mathrm{~S}\right] \mathrm{GTP}-\gamma-\mathrm{S}$ binding is expressed as a percentage over the baseline $[(($ stimulated - basal $) /$ basal $) \times 100 \pm$ SEM $]$.

\section{Electrophysiological recordings}

Mice were decapitated, and their brains were removed rapidly and immersed in ice-cold artificial CSF ( $\mathrm{aCSF}$ ) of the following composition (in mм): $126 \mathrm{NaCl}, 3.5 \mathrm{KCl}, 1.2 \mathrm{NaH}_{2} \mathrm{PO}_{4}, 1.3 \mathrm{MgCl}_{2}, 2.0 \mathrm{CaCl}_{2}, 25$ $\mathrm{NaHCO}_{3}$, and $11 \mathrm{D}$-glucose, continuously gassed with carbogen $(95 \%$ $\mathrm{O}_{2} / 5 \% \mathrm{CO}_{2}$ ) to maintain $\mathrm{pH}$ value at 7.3 .

A block of tissue containing the DRN was cut into $400 \mu \mathrm{m}$ thick coronal sections in the same ice-cold aCSF using a vibratome. Brainstem slices were immediately incubated in oxygenated aCSF for $\sim 1 \mathrm{hr}$ at room temperature. A single slice was then placed on a nylon mesh, completely submerged in the recording chamber, and continuously superfused with oxygenated aCSF $\left(34^{\circ} \mathrm{C}\right.$ ) at a constant flow rate of $2-3 \mathrm{ml} / \mathrm{min}$ (HajDahmane et al., 1991).

Extracellular recordings of the firing of DRN serotoninergic neurons were made using glass microelectrodes filled with $2 \mathrm{M} \mathrm{NaCl}(12-15 \mathrm{M} \Omega$ ). Cells were identified as 5-HT neurons according to previously described criteria (Haj-Dahmane et al., 1991). Firing was evoked in the otherwise silent neurons by adding the $\alpha_{1}$-adrenoceptor agonist phenylephrine ( 3 $\mu \mathrm{M}$ ) into the superfusing aCSF (VanderMaelen and Aghajanian, 1983).

Electrical signals were fed into a high-input impedance amplifier (VF 180; BioLogic, Claix, France), an oscilloscope, and an electronic rate meter triggered by individual action potentials, connected to an analogto-digital converter, and a personal computer (Haj-Dahmane et al., 1991). Using dedicated software, the integrated firing rate was recorded, computed, and displayed on a chart recorder as consecutive $10 \mathrm{sec}$ samples.

Baseline activity was recorded for at least $10 \mathrm{~min}$ before the infusion of increasing concentrations of the $5-\mathrm{HT}_{1 \mathrm{~A}}$ receptor agonist ipsapirone (Hamon, 1997), into the chamber, via a three-way tap system. Because complete exchange of fluids occurred within 2 min after the arrival of a new solution into the chamber, the duration of each application of ipsapirone was $3 \mathrm{~min}$. The effects of ipsapirone were evaluated by comparing the mean discharge frequency during the 2 min before its application with that recorded at the peak action of the drug (i.e., 2-3 min after its removal from the superfusing aCSF). Data are expressed as a percentage of the baseline firing rate \pm SEM. Nonlinear regression fitting was performed using Prism 2.0 software (Graph Pad, San Diego, CA) for the calculation of $\mathrm{EC}_{50}$ values of ipsapirone.

\section{Behavioral testing: decision-making task}

Behavioral testing was performed on the day immediately after the 4 week CMS session using a modified spontaneous alternation maze as described by Pardon et al. (2000). The apparatus consisted of three arms of equal dimensions ( $41.5 \mathrm{~cm}$ long, $6 \mathrm{~cm}$ wide, in gray Plexiglas) standing on a table $1 \mathrm{~m}$ above the floor. The central path and the right arm were "secure," because they were enclosed by transparent Plexiglas walls $(6 \mathrm{~cm}$ high) and roof. The left arm was considered to be potentially "insecure." It was suspended in the open above the floor, with several openings through the walls and no roof. The behavioral paradigm consisted of two trials separated by a $10 \mathrm{sec}$ interval. During the first trial, the mouse was forced to explore the "secure" arm, access to the other arm being blocked by a door. To begin the forced-reference trial, the animal was placed in the starting box, and after $10 \mathrm{sec}$, the door to the central path was opened. The trial was considered to be complete when the mouse had all four legs inside the goal box. No time limits were imposed. After a $5 \mathrm{sec}$ confinement in the goal box, the animal was removed and placed in the starting box for the test trial. Ten seconds later, the door was opened, and the animal had free access to the two arms. The trial was considered to be complete when the mouse had all four legs in one of the two goal boxes or after $5 \mathrm{~min}$ had elapsed. Behavioral testing was videotaped and subsequently analyzed. In the test trial, "choice" was considered to be made when the animal had reached a goal box before the time had elapsed, and "no choice" in case it had not (after $5 \mathrm{~min}$ ). The chosen option was noted: alternation, avoidance, or no choice. For the statistical analysis, an ordinal variable was constructed by affecting the value 2 to the alternation response, the value 1 to the avoidance response, and the value 0 to no 
choice. In both trials, the time that elapsed between opening the starting box door and closing goal box door [time to solve the task (TST)] was recorded with a maximum of $5 \mathrm{~min}$ for the test trial.

Statistical analyses

All data are given as means \pm SEM. Statistical analyses were performed using Prism 2.0 software (Graph Pad). For $5-\mathrm{HT}_{1 \mathrm{~A}}$ receptor-mediated $\left[{ }^{35} \mathrm{~S}\right] \mathrm{GTP}-\gamma$-S binding, GR mRNA in situ hybridization, GR and MR binding and serum corticosterone levels, a two-way ANOVA was performed with stress (stressed and unstressed mice) and genotype (WT and GR-i) as main factors and followed, in case of significant effect $(p<$ 0.05 ), by unpaired two-tailed Student's $t$ test to compare experimental and control groups. Extracellular recordings were analyzed by one-way ANOVA, and, in case of significance $(p<0.05)$, the F-test for significant treatment effects was followed by the unpaired two-tailed Student's $t$ test to compare the experimental groups with their control. For behavioral parameters, the three responses (alternation, avoidance, no choice) made by stressed and control mice of both GR-i and WT genotypes were compared using $\chi^{2}$ test. For analysis of both stress and genotype effects on TST, a two-way ANOVA was used to compare variances of both groups of mice in each trial. In case of significant effects of stress, genotype, or stress $\times$ genotype interaction, comparisons between groups were made using unpaired Student's $t$ test. $p$ values $\leq 0.05$ were considered significant for all the analyses.

\section{Chemicals}

$\left[{ }^{35} \mathrm{~S}\right] \mathrm{GTP}-\gamma-\mathrm{S},\left[{ }^{35} \mathrm{~S}\right] \mathrm{UTP}$, and $\left[1,2,6,7-{ }^{3} \mathrm{H}\right]$ corticosterone were purchased from Amersham Pharmacia Biotech. Other compounds were: WAY 100635 (N-[2-[4-(2-methoxyphenyl)1-piperazinyl]-ethyl]-N-(2pyridinyl)-cyclohexanecarboxamide; Wyeth-Ayerst, Princeton, NJ); GDP dilithium salt (Boehringer Mannheim); 5-CT, dexamethasone, phenylephrine, and DPCPX (Sigma, St. Quentin Fallavier, France); ipsapirone (Troponwerke Bayer, Cologne, Germany); mifepristone (Roussel Uclaf, Romainville, France).

\section{Results}

\section{Characterization of GR-i compared with WT mice}

Serum corticosterone levels

Under control conditions (i.e., in the absence of stress), serum corticosterone levels were similar in WT $(6.00 \pm 0.89 \mu \mathrm{g} / 100 \mathrm{ml}$; mean \pm SEM; $n=8)$ and GR-i $(6.16 \pm 1.04 \mu \mathrm{g} / 100 \mathrm{ml}$; mean \pm SEM; $n=14)$ mice. After a 4 week CMS, serum corticosterone levels were found to be increased in WT mice $(10.71 \pm 2.36$ $\mu \mathrm{g} / 100 \mathrm{ml}$; mean $\pm \mathrm{SEM} ; n=10, p<0.001)$ but not in GR-i mice $(6.70 \pm 1.88 \mu \mathrm{g} / 100 \mathrm{ml}$; mean $\pm \mathrm{SEM} ; n=6$; NS $)$ compared with their respective controls.

\section{Dexamethasone suppression test}

One hour after injection, serum corticosterone levels were markedly lower in WT mice that had received dexamethasone $(2 \mu \mathrm{g} /$ 100 gm, i.p.) compared with saline (Fig. 1). In contrast, serum levels of the endogenous corticosteroid were not significantly different $1 \mathrm{hr}$ after acute administration of either dexamethasone or saline in GR-i transgenic mice (Fig. 1). In both WT and GR-i mice, corticosterone levels in saline-injected animals were twoto threefold higher $(p<0.05)$ than those found under control conditions (see above), as expected from HPA activation by intraperitoneal injection.

GR and MR binding sites

Quantification of GR binding sites specifically labeled by $\left[{ }^{3} \mathrm{H}\right]$ corticosterone in the cytosolic fraction revealed an $\sim 50 \%$ decrease in their $B_{\max }$ values in both the hippocampus and the cerebral cortex of GR-i mice compared with WT mice (Table 1). In contrast, MR binding sites, which were less abundant than GR binding sites in these two brain areas in WT mice, had similar $B_{\max }$ values in both groups (Table 1 ).

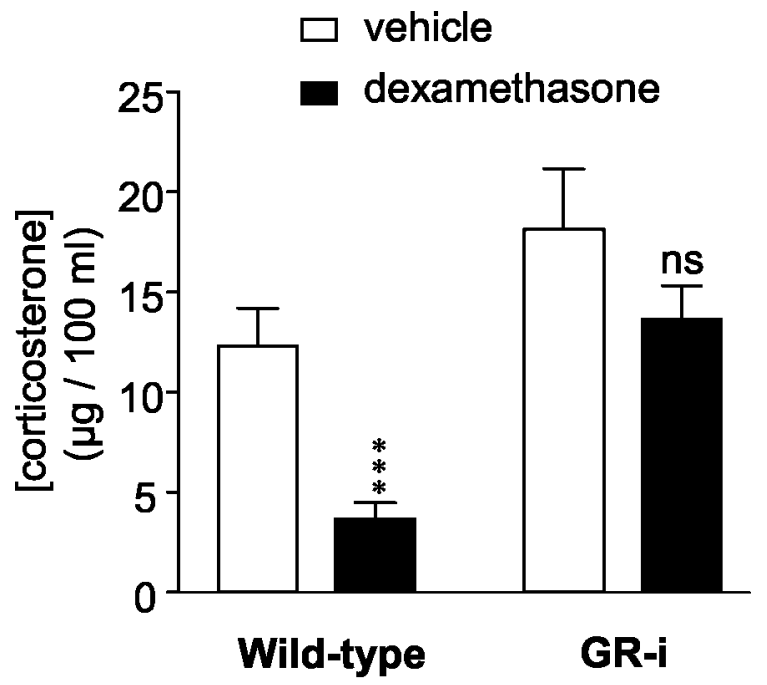

Figure 1. Dexamethasone suppression test. Serum corticosterone levels (in $\mu \mathrm{g} / 100 \mathrm{ml}$ ) were measured $1 \mathrm{hr}$ after injection of dexamethasone ( $2 \mu \mathrm{g} / 100 \mathrm{gm}$ body weight, i.p.) or its vehicle ( $0.5 \%$ ethanol in $0.9 \% \mathrm{NaCl}$, i.p., $1 \mathrm{ml} / 100 \mathrm{gm})$ to wild-type and transgenic GR-i mice. Each bar is the mean \pm SEM of measurements in 11-12 mice per group. ns, Non significant; ${ }^{* * *} p<0.001$, compared with vehicle-injected mice of the same genotype (unpaired Student's $t$ test).

\section{Biochemical, electrophysiological, and behavioral effects of} CMS in GR-i mice compared with WT mice

\section{GR $m R N A$ in situ hybridization}

In unstressed mice. Densitometric quantification of the hybridization signal showed a significant decrease in GR mRNA levels in the hippocampus $(-30 \%)$ and the cerebral cortex $(-53 \%)$ of GR-i transgenic mice $(0.60 \pm 0.05$ and $0.30 \pm 0.04$, mean OD values \pm SEM, $n=4$, in these two brain structures, respectively) compared with paired WT controls $(0.86 \pm 0.06$ and $0.64 \pm 0.18$, $n=3$, respectively; $p<0.05)$. In the $\mathrm{DRN}$, the decrease $(-28 \%)$ in GR mRNA levels in GR-i mice $(0.130 \pm 0.018 ; n=4)$ versus WT mice $(0.180 \pm 0.024, n=4)$ did not reach the critical level of significance (Figs. 2, 3).

Effects of CMS. After a 4 week CMS, hippocampal GR mRNA levels were significantly decreased $(-33 \%)$ in WT mice $(0.58 \pm$ 0.05 ; mean OD values \pm SEM; $n=5 ; p<0.05)$, whereas they were markedly increased $(+83 \%)$ in GR-i mice $(1.10 \pm 0.09 ; n=$ $5 ; p<0.01)$, compared with their respective unstressed controls (Figs. 2, 3A).

In the cerebral cortex, CMS exposure failed to significantly modify GR mRNA levels in WT mice $(0.74 \pm 0.09 ; n=5 ; p=$ $0.55)$. In contrast, a marked increase $(+42 \%)$ in cortical GR mRNA levels was observed in stressed GR-i mice $(0.91 \pm 0.07$; $n=5 ; p<0.001$ ) compared with unstressed GR-i mice (Fig. 2, 3B).

In the DRN, CMS exposure produced an increase in GR mRNA levels in both genotypes. However, because of large interindividual variations in the second group, this change was significant in WT mice $(0.270 \pm 0.018 ; n=5 ;+50 \% ; p<0.05)$ but not in GR-i mice $(0.220 \pm 0.061 ; n=3)$ as compared with their respective unstressed controls (Fig. 2, 3C).

\section{GR binding sites}

In unstressed mice. As previously found in naive animals (see above), quantification of cytosolic GR binding sites specifically labeled by $\left[{ }^{3} \mathrm{H}\right]$ corticosterone showed a significant decrease in both the hippocampus $(-45 \%)$ and the cerebral cortex $(-57 \%)$ of unstressed GR-i mice compared with paired unstressed WT mice $(p<0.05)$ (Fig. 4$)$. 
Table 1. $B_{\max }$ values of $\mathrm{GR}$ and MR cytosolic binding sites specifically labeled by $\left[{ }^{3} \mathrm{H}\right]$ corticosterone in the hippocampus and the cerebral cortex of GR-i mice compared with WT mice

\begin{tabular}{|c|c|c|c|c|}
\hline & \multicolumn{4}{|c|}{$\left[{ }^{3} \mathrm{H}\right]$ Corticosterone specifically bound, $B_{\max }(\mathrm{fmol} / \mathrm{mg}$ protein) } \\
\hline & \multicolumn{2}{|l|}{ GR } & \multicolumn{2}{|l|}{ MR } \\
\hline & WT $(n=3)$ & GR-I $(n=4)$ & $\mathrm{WT}(n=3)$ & GR-I $(n=4)$ \\
\hline Hippocampus & $29.4 \pm 3.5$ & $14.4 \pm 2.7^{*}(-51 \%)$ & $11.0 \pm 1.4$ & $12.0 \pm 3.6$ (ns) \\
\hline Cerebral cortex & $11.8 \pm 1.7$ & $6.0 \pm 1.3^{*}(-49 \%)$ & $4.5 \pm 1.4$ & $6.3 \pm 2.3$ (ns) \\
\hline
\end{tabular}

$B_{\max }$ is expressed as femtomoles $\left[{ }^{3} \mathrm{H}\right]$ corticosterone specifically bound per milligram of protein. Each value is the mean \pm SEM of $n$ independent determinations. ns, Nonsignificant; ${ }^{*} p<0.05$, compared with respective values in WT mice (unpaired Student's $t$ test).

\section{DRN}

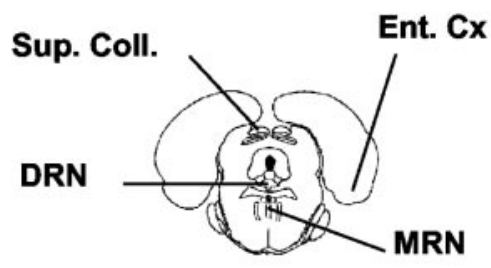

\section{Hippocampus / Cortex}

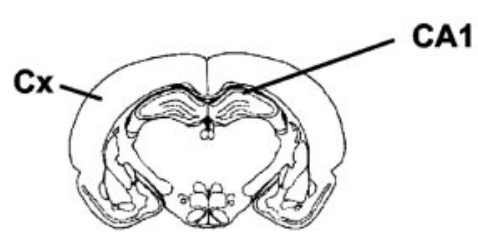

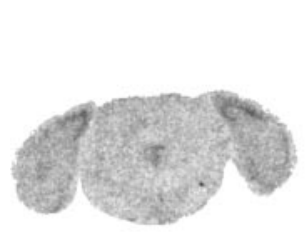

unstressed

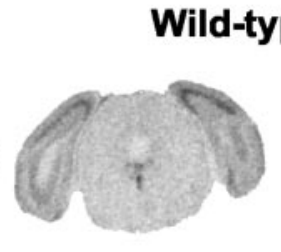

stressed

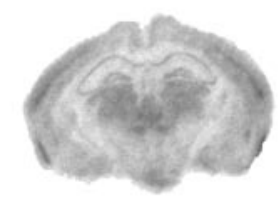

unstressed

\section{GR-i mice}

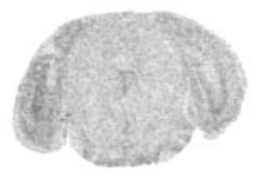

unstressed

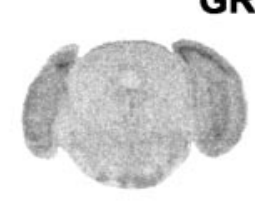

stressed

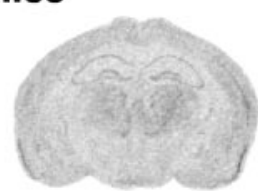

unstressed

Figure 2. Representative autoradiograms of GR mRNA in situ hybridization in brain sections from GR-i and wild-type mice. Comparison between stressed and unstressed animals. Brain sections $(20 \mu \mathrm{m})$ were prepared from mice decapitated between 9.00 and 10.00 A.M. on the day immediately after a 4 week exposure to mild stress or nonstress conditions. Sections at the level of the DRN, cerebral cortex, and hippocampus were labeled by $\left[{ }^{35} S\right] U T P$ antisense RNA probe specific to mouse GR mRNA sequence. Similar autoradiograms were obtained from four to five mice per group. CA1, CA1 area of Ammon's horn; Cx, cerebral cortex; Ent. Cx, entorhinal cortex; MRN, median raphe nucleus; Sup. Coll., superior colliculi.

In stressed mice. In WT mice, exposure to a 4 week CMS produced a significant reduction $(p<0.05)$ in the density of GR binding sites in both the hippocampus $(-40 \%)$ and the cerebral cortex $(-60 \%)$ (Fig. 4). In contrast, GR binding sites were significantly increased in the hippocampus $(+43 \% ; p<0.05)$ of stressed, compared with unstressed, GR-i mice (Fig. 4). In the cerebral cortex, a nonsignificant tendency to an increase $(+26 \%$; $p=0.33$ ) in the density of GR binding sites was also noted in GR-i mice that had been subjected to CMS (Fig. 4).

\section{5- $\mathrm{HT}_{1 \mathrm{~A}}$ receptor-mediated $\left[\gamma_{-}{ }^{35} \mathrm{~S}\right] \mathrm{GTP}-\mathrm{S}$ binding}

In unstressed mice. In both WT and GR-i mice, 5-CT $(10 \mu \mathrm{M})$ markedly increased the autoradiographic labeling of both the CA1 area in the hippocampus and the DRN by $\left[{ }^{35} \mathrm{~S}\right] \mathrm{GTP}-\gamma-\mathrm{S}$ (Table 2 ). This effect was completely prevented by the $5-\mathrm{HT}_{1 \mathrm{~A}}$ receptor antagonist WAY $100635(10 \mu \mathrm{M})$, and $\left[{ }^{35} \mathrm{~S}\right] \mathrm{GTP}-\gamma-\mathrm{S}$ binding in the presence of both 5-CT and WAY 100635 did not

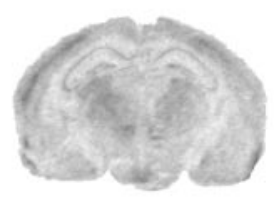

stressed

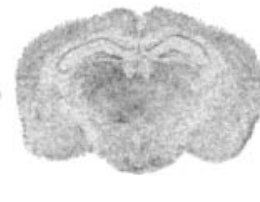

stressed significantly differ from that measured under basal conditions in the two regions (data not shown). In both genotypes, 5 -CT-induced increase in $\left[{ }^{35} \mathrm{~S}\right] \mathrm{GTP}-\gamma-\mathrm{S}$ binding was three- to fourfold higher in the CA1 hippocampal area than in the DRN (Table 2).

Effects of CMS. As shown in Table 2, neither in WT mice nor in GR-i mutants, a 4 week exposure to CMS was found to alter 5 -CT-induced increase in $\left[{ }^{35} \mathrm{~S}\right] \mathrm{GTP}-\gamma$-S binding in the CA1 hippocampal area as well as in the DRN.

\section{Electrophysiological activity of DRN} serotoninergic neurons

In unstressed mice. DRN serotoninergic neurons recorded in brainstem slices from WT mice displayed the characteristic slow $(1.86 \pm 0.16$ spikes/sec; mean \pm SEM; $n=$ 22 ) and regular pattern of discharge as described previously in rodents (HajDahmane et al., 1991; Froger et al., 2001). No differences in both the frequency $(1.87 \pm 0.28$ spikes/sec; $n=16)$ and the discharge pattern of DRN serotoninergic neurons were observed in GR-i mice compared with WT mice.

As expected from the stimulation of somatodendritic 5- $\mathrm{HT}_{1 \mathrm{~A}}$ autoreceptors (Froger et al., 2001), the addition of the $5-\mathrm{HT}_{1 \mathrm{~A}}$ receptor agonist ipsapirone into the aCSF superfusing brainstem slices resulted in a concentration-dependent inhibition of the firing of DRN 5-HT neurons (Fig. 5). This effect reached its maximum 2-3 min after the application of ipsapirone (10 nM to $10 \mu \mathrm{M}$ ) and was progressively washed out. As shown in Figure $5, B$ and $D$, the potency of ipsapirone to inhibit 5-HT neuron firing was similar in unstressed GR-i and WT mice. $\mathrm{EC}_{50}$ values of the $5-\mathrm{HT}_{1 \mathrm{~A}}$ receptor agonist were $62.1 \pm 1.8 \mathrm{nM}$ $($ mean \pm SEM; $n=22)$ for WT mice and $54.4 \pm 1.1 \mathrm{nM}(n=16)$ for GR-i mutants.

Effects of CMS. After a 4- week exposure to CMS, no modifications of the spontaneous firing rate of DRN serotoninergic neurons were observed in WT $(1.90 \pm 0.26$ spikes/sec; $n=9)$ as well as GR-i ( $1.65 \pm 0.17$ spikes/sec; $n=10)$ mice compared with that recorded in paired unstressed controls (see above).

In the WT group, the addition of ipsapirone into the aCSF superfusing brainstem slices caused a concentration-dependent inhibition of the firing of DRN serotoninergic neurons that was less pronounced in stressed, than in unstressed, animals (Fig. 

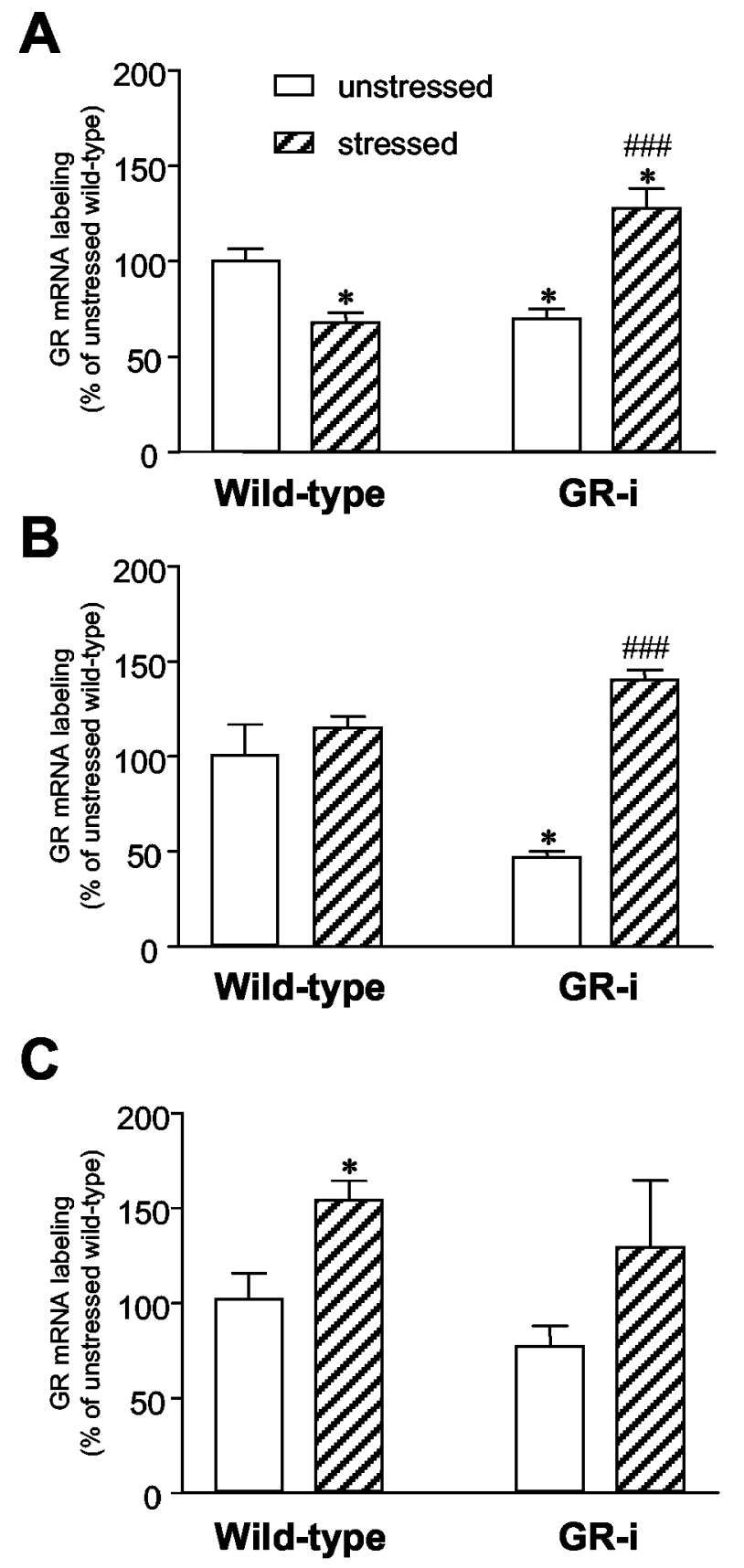

Figure 3. Quantification of GR $m R N A$ in situ hybridization labeling within the hippocampus (CA1 area; $A$ ), the cerebral cortex $(B)$, and the DRN ( $C$ ) in transgenic GR-i and wild-type mice. Effects of CMS. The experimental protocol was as described in the legend to Figure 2. GR mRNA labeling is expressed as a percentage of respective OD values in unstressed wild-type mice. Bars are the means \pm SEM of independent determinations in four to five mice per group. ${ }^{*} p<0.05$, compared with unstressed wild-type mice; ${ }^{\# \# \#} p<0.001$, compared with unstressed GR-i mice (unpaired Student's $t$ test).

$5 A)$. The resulting shift to the right of the concentration-response curve (Fig. $5 B$ ) indicated a significant decrease in the potency of ipsapirone in stressed WT mice $\left(\mathrm{EC}_{50}=142.6 \pm 11.6 \mathrm{nM} ; n=8\right.$; $p<0.05)$ compared with unstressed WT mice (see above).

In contrast, no modifications of the concentration-response curve of ipsapirone were noted in stressed GR-i mice $\left(\mathrm{EC}_{50}=\right.$ $58.2 \pm 3.0 \mathrm{nM} ; n=10)$ compared with unstressed animals of the same genotype (Fig. $5 C, D$ ).
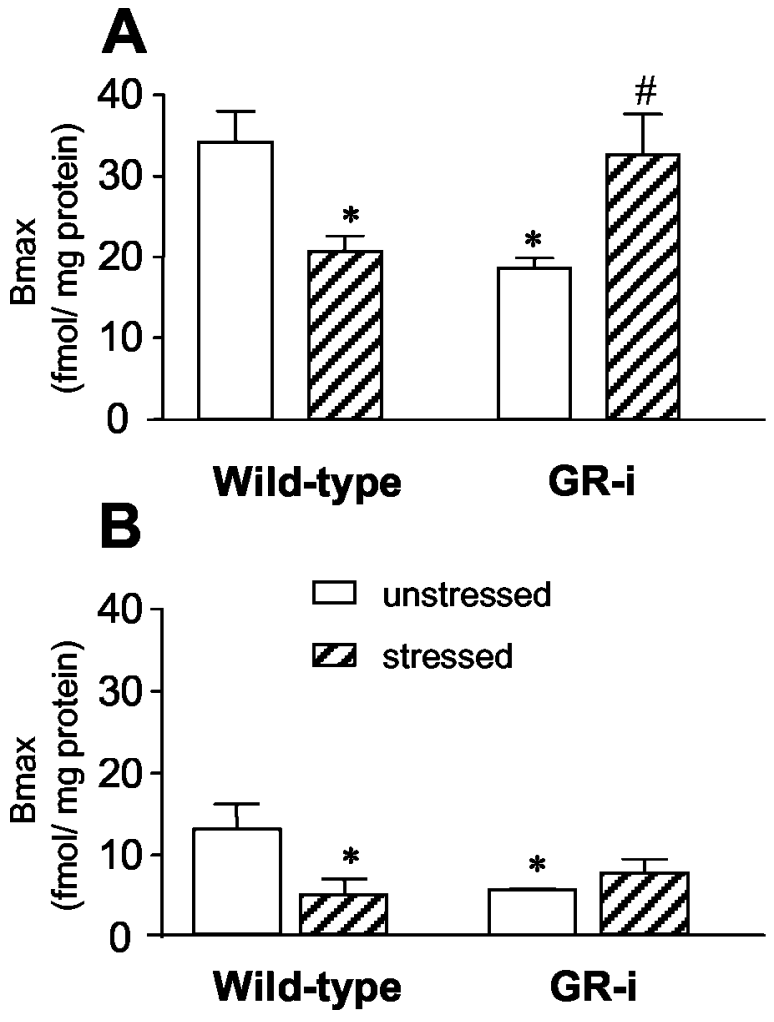

Figure 4. $B_{\max }$ values of $G R$ cytosolic binding sites specifically labeled by $\left[{ }^{3} \mathrm{H}\right]$ corticosterone in the hippocampus $(A)$ and the cerebral cortex (B) of GR-i mutants compared with wild-type mice. Effects of chronic mild-stress. Binding assays were performed on cytosolic extracts prepared from mice killed on the day immediately after a 4 week exposure to mild stress or nonstress conditions. $B_{\max }$ is expressed as femtomoles $\left[{ }^{3} \mathrm{H}\right]$ corticosterone specifically bound per milligram of protein. Each bar is the mean \pm SEM of three to five independent determinations. ${ }^{*} p<0.05$, compared with respective values in unstressed wild-type mice; ${ }^{\#} p<0.05$, compared with unstressed GR-i mice (unpaired Student's $t$ test).

\section{Behavioral testing: decision-making task}

Response distribution

In unstressed mice. The distribution of the three possible responses (alternation, avoidance, no choice) was not significantly different between unstressed WT $(n=28)$ and GR-i $(n=24)$ mice $\left(\chi^{2}=2.51 ; p=0.28\right)$. In both genotypes, the avoidance response was the most frequent choice (WT mice: $71.4 \%, n=20$; GR-i mutants: $50.0 \%, n=12$ ), and alternation and no choice were equally distributed (WT mice: $14.3 \%, n=4$ each; GR-i mutants: 25\%, $n=6$ each) (Fig. 6)

Effects of CMS. A 4 week exposure to CMS induced significant modifications of the distribution of the three responses in WT mice $\left(\chi^{2}=4.907 ; p=0.027\right)$ but not in GR-i mutants. The no choice response was no longer present in WT mice that had been subjected to CMS $(n=20)$. Avoidance and alternation represented $65.0 \%(n=13)$ and $35.0 \%(n=7)$ of all the responses in these animals, respectively. Accordingly, the no choice response disappeared at the benefit of the alternation response, which was $\sim 2.5$-fold more frequent in stressed WT mice compared with unstressed WT mice. In contrast, in GR-i mice $(n=20)$, stress exposure modified only marginally the distribution of the responses, compared with that for paired unstressed mutants. After the 4 week CMS, the choice made by GR-i mice of avoidance $(35.0 \% ; n=7)$, alternation $(50.0 \% ; n=10)$, and no choice $(15.0 \% ; n=3)$ were not significantly $\left(\chi^{2}=2.98 ; p=0.22\right)$ different from those made by unstressed animals of the same genotype (see above) (Fig. 6) 
Table 2.5- $\mathrm{HT}_{1 \mathrm{~A}}$ receptor-mediated increase in $\left[{ }^{35} \mathrm{~S}\right] \mathrm{GTP}-\gamma$-S binding within the DRN and the hippocampus (CA1 area) in transgenic GR-i and WT mice: effects of CMS

\begin{tabular}{|c|c|c|c|c|}
\hline & \multicolumn{4}{|c|}{ 5-HT ${ }_{1 \mathrm{~A}}$ Receptor-mediated $\left[\gamma^{-35} \mathrm{~S}\right] \mathrm{GTP}-\mathrm{S}$ binding (\% increase) } \\
\hline & \multicolumn{2}{|c|}{ Hippocampus (CA1) } & \multicolumn{2}{|l|}{ DRN } \\
\hline & Unstressed & Stressed & Unstressed & Stressed \\
\hline WT & $+317 \pm 29$ & $+320 \pm 21$ (ns) & $+78.8 \pm 4.9^{* * *}$ & $+81.3 \pm 8.2^{* * *}$ (ns) \\
\hline GR-i & $+287 \pm 33$ & $+263 \pm 5$ (ns) & $+90.4 \pm 20.5^{* * *}$ & $+69.4 \pm 14.0^{* * *}$ (ns) \\
\hline
\end{tabular}

Wild-type mice

A ipsapirone (nM)

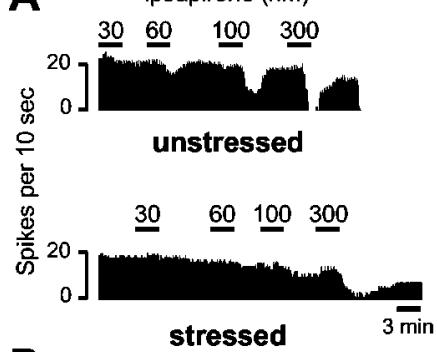

B

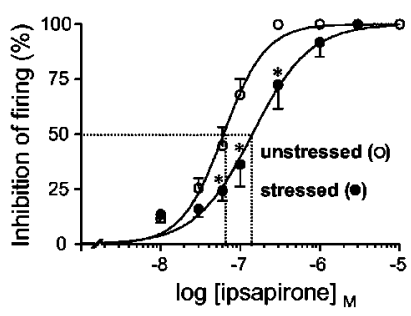

GR-i mice

ipsapirone (nM)

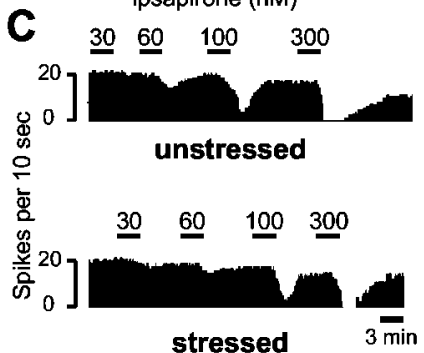

D

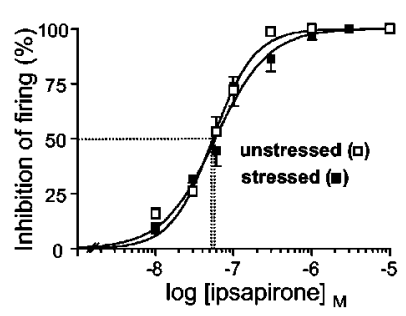

Figure 5. Effects of CMS on ipsapirone-induced inhibition of the firing of DRN5-HT neurons. Comparison between $G R$-i and wild-type mice. Experiments were performed on the day immediately after a 4 week exposure to mild stress or nonstress conditions. $A$, Integrated firing rate histograms (in spikes per $10 \mathrm{sec}$ ) showing the inhibitory effect of increasing concentrations of ipsapirone on the electrical activity of a DRN 5-HT neuron in a control, unstressed, and a stressed wild-type mouse. $B$, Concentration-response curves of ipsapirone-induced inhibition of the firing of DRN 5-HT neurons in wild-type mice. Each point is the mean \pm SEM of data obtained from 22 and 9 individual cells in unstressed and stressed mice, respectively. The dotted lines illustrate the $\mathrm{EC}_{50}$ values of ipsapirone (abscissa) in both groups. C, Integrated firing rate histograms (in spikes per $10 \mathrm{sec}$ ) showing the inhibitory effect of increasing concentrations of ipsapirone on the electrical activity of a DRN 5-HT neuron in a control, unstressed, and a stressed GR-i mouse. $D$, Concentration-response curves of ipsapirone-induced inhibition of the firing of DRN 5-HT neurons in GR-i mice. Each point is the mean \pm SEM of data obtained from 16 and 10 individual cells in unstressed and stressed GR-i mice, respectively. The dotted lines illustrate the $\mathrm{EC}_{50}$ values of ipsapirone (abscissa) in unstressed and stressed GR-i mice. ${ }^{*} p<0.05$, compared with corresponding values in control mice.

Time to solve the task

In unstressed animals, TST for both the first $\left(\mathrm{TST}_{1}\right)$ and the second $\left(\mathrm{TST}_{2}\right)$ trials of behavioral testing were similar in GR-i and WT mice (Table 3 ). After the 4 week CMS, TST 1 was significantly shortened in WT mice but not in GR-i mutants. In contrast, $\mathrm{TST}_{2}$ was not significantly affected by stress in both groups. However, a two-way ANOVA analysis revealed a significant effect of genotype ( $p=0.009)$, because $\mathrm{TST}_{2}$ tended to decrease in WT mice $(-33 \%)$ and to increase in GR-i mice $(+10 \%)$ after the 4 week stress session (Table 3).

\section{Discussion}

Depression is a multifactorial disease that can proceed from the dysfunction of neurotransmitter and endocrine systems resulting

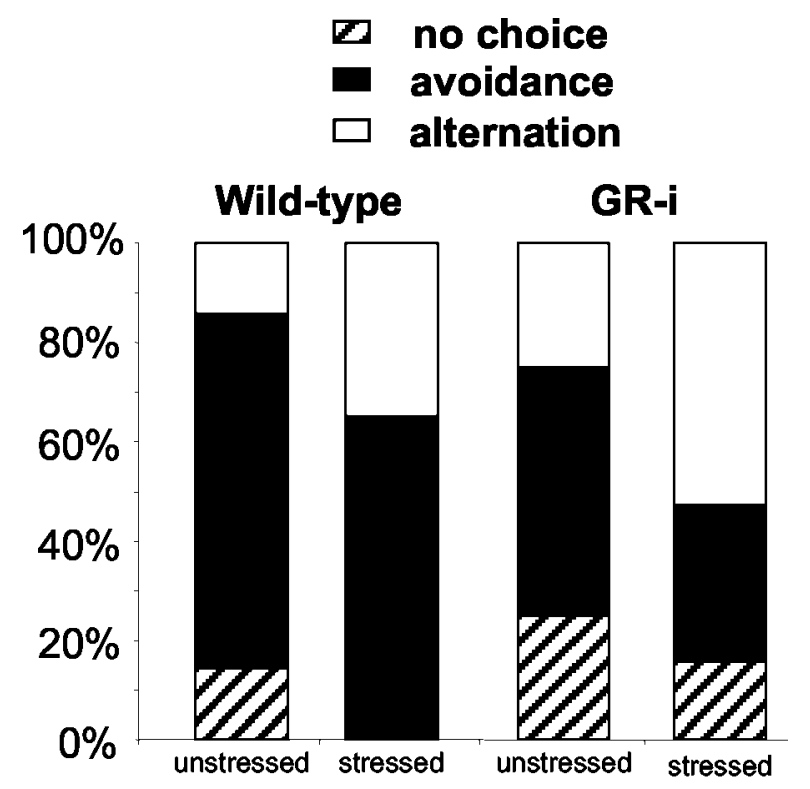

Figure 6. Effects of CMS on the distribution of behavioral responses in the decision-making task. Comparison between GR-i and wild-type mice. Experiments were performed on the day immediately after a 4 week exposure to mild stress or nonstress conditions. A total of 28 unstressed and 20 stressed mice of the wild-type genotype were tested; the corresponding numbers for GR-i mice were 24 and 20, respectively. Results are expressed as percentages of mice that displayed no choice, avoidance, or alternation response in each group.

from a combination of genetic and environmental factors. In the present study, such a combination was achieved by exposing transgenic GR-i mice with altered HPA activity (Pepin et al., 1992 ) to CMS. Neurochemical, electrophysiological, and behavioral investigations of this model clearly showed that GR-i mice exhibit different responses than WT mice to chronic stress.

GRs are involved in the negative feedback control of corticosterone secretion, and downregulation of GR might result in a tonic increase in HPA axis activity, thereby mimicking HPA basal hyperactivity that seems to be frequently associated with depression (Holsboer and Barden, 1996). GR-i mice bearing a transgene encoding antisense GR RNA driven by a neurofilament promoter (Pepin et al., 1992) were found to be unresponsive to the dexamethasone suppression test, in contrast to WT mice in which administration of the synthetic corticosteroid significantly decreased serum corticosterone levels (Barden et al., 1997). Such a marked reduction in the efficiency of negative feedback regulation of HPA axis seemed to be causally related to GR downregulation that occurred predominantly in the brain in GR-i mutants (Barden et al., 1997). Indeed, we confirmed that $\left[{ }^{3} \mathrm{H}\right]$ corticosterone binding to cytosolic GR, but not $\mathrm{MR}$, in the cerebral cortex and the hippocampus, and GR mRNA levels in these areas and the DRN, were downregulated in GR-i mice. Interestingly, the 
Table 3. Effect of CMS on the TST in trials 1 and 2 of the decision-making task in WT and GR-i mice

\begin{tabular}{|c|c|c|c|c|}
\hline & \multicolumn{4}{|l|}{ TST (seconds) } \\
\hline & \multicolumn{2}{|l|}{ WT } & \multicolumn{2}{|l|}{ GR-i } \\
\hline & Unstressed & Stressed & Unstressed & Stressed \\
\hline $\mathrm{TST}_{1}$ & $70.9 \pm 12.9(n=28)$ & $39.6 \pm 4.0^{*}(n=19)$ & $89.7 \pm 18.7(n=20)$ & $79.1 \pm 15.2^{* *}(n=20)$ \\
\hline $\mathrm{TST}_{2}$ & $55.8 \pm 14.0(n=22)$ & $37.2 \pm 6.2(n=19)$ & $82.7 \pm 20.8(n=18)$ & $91.2 \pm 15.8^{* * *}(n=17)$ \\
\hline
\end{tabular}

decrease in GR mRNA levels (30-40\%) was lower than that in GR binding sites density (50\%). This quantitative difference might be related to the fact that binding assays allowed measurement of cytosolic GR only and not of GR translocated into the cell nucleus. Unfortunately, this hypothesis could not be tested in the present studies because not enough nuclear extracts could be prepared from dissected mouse brain areas to perform $\left[{ }^{3} \mathrm{H}\right]$ corticosterone binding assays.

To assess HPA axis feedback activity after CMS exposure, we measured GR mRNA levels and the density of GR binding sites in the hippocampus and cerebral cortex, two areas critically involved in negative feedback function (Mizoguchi et al., 2003). In WT mice, CMS downregulated GR in the hippocampus but not in the cerebral cortex, as already reported in rats (Kitraki et al., 1999; Mizoguchi et al., 2001). GR downregulation was very probably at the origin of HPA axis hyperactivity induced by CMS, as shown by serum corticosterone levels that were markedly elevated in CMS-exposed WT mice. In contrast, in GR-i mice, CMS did not trigger GR downregulation, and, indeed, both GR mRNA levels and the density of GR binding sites in the hippocampus as well as the cerebral cortex were actually increased in stressed mutants. Furthermore, serum corticosterone levels did not increase after CMS, like that reported by Linthorst et al. (2000), in GR-i mice subjected to a psychological stressor. Preliminary data showed that GR-i mice that had been subjected to CMS were sensitive to the inhibitory effect of dexamethasone on corticosterone secretion [serum corticosterone levels: $4.9 \pm 0.5 \mu \mathrm{g} / 100 \mathrm{ml}$ $(n=3)$ vs $11.5 \pm 2.3 \mu \mathrm{g} / 100 \mathrm{ml}(n=3)$ in dexamethasone- vs saline-injected mice, respectively; $p<0.05$ ], in contrast to unstressed GR-i mutants that were resistant to the dexamethasone suppression test [serum corticosterone levels: $9.5 \pm 2.1 \mu \mathrm{g} / 100$ $\mathrm{ml}(n=3)$ vs $8.7 \pm 2.5 \mu \mathrm{g} / 100 \mathrm{ml}(n=3)$ in dexamethasone- vs saline-injected mice, respectively; NS]. Accordingly, the failure of CMS to increase serum corticosterone levels in GR-i mice might reflect stress-induced restoration of functional HPA-negative feedback control in these mutants. In contrast, previous data in WT rodents showed that CMS-induced downregulation of hippocampal GR is associated with the loss of HPA feedback control (Mizoguchi et al., 2003), thereby possibly explaining why WT mice exhibited a marked increase in serum corticosterone levels after CMS exposure.

In the DRN, a significant increase in GR mRNA levels was observed in CMS-exposed WT mice, in line with previous studies showing an increased GR expression in this nucleus after chronic restraint stress in rats (Kitayama et al., 1989). In GR-i mice also, DRN GR mRNA levels tended to increase (but not significantly) after CMS exposure. Accordingly, in contrast to that observed in the hippocampus, GR mRNA regulation in the DRN was not qualitatively different in the two genotypes. The difference in the stress effect on GR mRNA in the hippocampus (decrease) versus the DRN (increase) in WT mice suggests that GR regulation is structure dependent, as also evidenced for the 5-HT-mediated control of GR expression (Héry et al., 2000).
Because $5-\mathrm{HT}_{1 \mathrm{~A}}$ receptors are known to play key roles in reciprocal interactions between the HPA axis and 5-HT neurotransmission (Laaris et al., 1995, 1999; Chaouloff, 2000), electrophysiological and pharmacological investigations were used to evaluate $5-\mathrm{HT}_{1 \mathrm{~A}}$ autoreceptor functioning in the two genotypes under basal conditions and after CMS exposure. Consistent with previous data (Lanfumey et al., 1999), bath application of a $5-\mathrm{HT}_{1 \mathrm{~A}}$ receptor agonist, ipsapirone, induced a concentrationdependent inhibition of DRN 5-HT neuron firing in brainstem slices from WT and GR-i mice. Interestingly, this effect was similar in both strains, in line with additional data showing that $5-\mathrm{HT}_{1 \mathrm{~A}}$ receptor-mediated increase in $\left[{ }^{35} \mathrm{~S}\right] \mathrm{GTP}-\gamma-\mathrm{S}$ binding by 5 -CT in the DRN was identical in GR-i mutants and paired WT mice.

After CMS exposure, the potency of ipsapirone to inhibit the discharge of DRN 5-HT neurons was significantly reduced in WT mice, being $\sim 2$.3-fold lower in stressed, than in unstressed, animals. As already described in both B6D2F1 mice exposed to the same stress procedure (Lanfumey et al., 1999) and in normal rats stressed by a novel environment (Laaris et al., 1999), the decreased potency of the $5-\mathrm{HT}_{1 \mathrm{~A}}$ receptor agonist suggests the occurrence of a functional desensitization of DRN 5-HT $1 \mathrm{~A}$ autoreceptors as a response to increased HPA axis activity. However, the $5-\mathrm{HT}_{1 \mathrm{~A}}$ receptor-mediated increase in $\left[{ }^{35} \mathrm{~S}\right] \mathrm{GTP}-\gamma-\mathrm{S}$ binding by 5 -CT was similar in the DRN of control and stressed WT mice, suggesting that $5-\mathrm{HT}_{1 \mathrm{~A}}$ autoreceptor desensitization induced by stress was not attributable to a receptor downregulation (Laaris et al., 1999) or a decrease in its coupling with G-proteins. The mechanisms underlying stress-induced functional desensitization of 5- $\mathrm{HT}_{1 \mathrm{~A}}$ autoreceptors are, therefore, different from those responsible for the similar adaptive phenomenon occurring after chronic treatment with antidepressants that selectively inhibit serotonin reuptake. Indeed, a marked reduction in $5-\mathrm{HT}_{1 \mathrm{~A}}$ receptor-G-protein coupling within the DRN has been reported in rodents after chronic treatment with such drugs (Hensler, 2002; Pejchal et al., 2002).

In contrast to that observed in WT mice, no $5-\mathrm{HT}_{1 \mathrm{~A}}$ autoreceptor desensitization occurred in GR-i mice that had been subjected to CMS. This observation provides indirect support to the hypothesis that GR activation within the DRN normally underlies this phenomenon (Laaris et al., 1995, 1999). Indeed, WT mice exhibited marked increases in both circulating corticosterone levels and local GR expression in response to chronic stress, and the resulting enhanced GR signaling was actually expecting to trigger functional desensitization of $5-\mathrm{HT}_{1 \mathrm{~A}}$ autoreceptors (Laaris et al., 1995). In contrast, neither serum corticosterone levels nor GR expression in the DRN were significantly increased in response to chronic stress in GR-i mice, and the resulting lack of changes in GR signaling matched the absence of 5-HT 1 A autoreceptor desensitization in the stressed mutants. Accordingly, in GR-i mice, 5- $\mathrm{HT}_{1 \mathrm{~A}}$ autoreceptor functioning seemed to be normal under basal conditions, but its expected adaptive changes in 
response to chronic stress were lost because of HPA axis abnormalities.

Finally, behavioral investigations also revealed marked differences in the effects of CMS on GR-i mice compared with WT mice. Using an alternation paradigm for the assessment of decision making (Pardon et al., 2000), we found that CMS exposure apparently improved decision making in WT mice, because (1) the "non-choice" response, which was present in $\sim 15 \%$ of unstressed animals, disappeared after CMS, and (2) the TST index was consistently lower in stressed, than in unstressed, mice. These data are in accordance with those showing that stress could induce a faster processing of environmental information, associated with a higher level of risk assessment in mice (Pardon et al., 2000). Interestingly, this response to stress was not observed in GR-i mice. Thus, neither the distribution of responses (alternation, avoidance, non-choice), nor the TST index were significantly modified after CMS in mutant mice with GR-i function. Therefore, GR-i mice appeared to be unable to adapt their behavior in this decision-making task after CMS exposure.

Taken together, the neurochemical, electrophysiological, and behavioral data reported here emphasize the existence of profound deficits in the adaptive responses to chronic stress in GR-i mutants compared with paired WT mice. Both HPA (corticosterone levels and GR expression) and 5-HT (5-HT $\mathrm{HA}_{1 \mathrm{~A}}$ autoreceptor functioning) indices, as well as behavioral data, showed that GR impairment prevents normal adaptive changes in response to daily mild stressors that reproduce repetitive stressful life events like those possibly causing depression in human (Post, 1992). These data further confirm that the GR-i mouse is a relevant genetic model to assess how stress can contribute to trigger neurobiological and behavioral deficits associated with depression.

\section{References}

Arango V, Underwood MD, Boldrini M, Tamir H, Kassir SA, Hsiung SC, Chen JJX, Mann JJ (2001) Serotonin SA $_{1 \mathrm{~A}}$ receptors, serotonin transporter binding and serotonin transporter mRNA expression in the brainstem of depressed suicide victims. Neuropsychopharmacology 25:892-903.

Barden N (1999) Regulation of corticosteroid receptor gene expression in depression and antidepressant action. J Psychiatry Neurosci 24:25-39.

Barden N, Stec I, Montkowski A, Holsboer F, Reul JM (1997) Endocrine profile and neuroendocrine challenge test in transgenic mice expressing antisense RNA against the glucocorticoid receptor. Neuroendocrinology 66:212-220.

Breslau N, Schultz L, Peterson E (1995) Sex differences in depression: a role for preexisting anxiety. Psychiatry Res 58:1-12.

Cadoret RJ, O'Gorman TW, Heywood E, Troughton E (1985) Genetic and environmental factors in major depression. J Affect Disord 9:155-164.

Cadoret RJ, Winokur G, Langbehn D, Troughton E, Yates WR, Stewart MA (1996) Depression spectrum disease, I: The role of gene-environment interaction. Am J Psychiatry 153:892-899.

Carrol BJ, Feinberg M, Greden JF, Tarika J, Albala AA, Haskett RF, James NM, Kronfol Z, Lohr N, Steiner M, De Vigne JP, Young E (1981) A specific laboratory test for the diagnosis of melancholia. Standardization, validation and clinical stability. Arch Gen Psychiatry 38:15-22.

Chaouloff F (2000) Serotonin, stress and corticoids. J Psychopharmacol 14:139-151.

Danielsen M, Northrop JP, Ringold GM (1986) The mouse glucocorticoid receptor: mapping of functional domains by cloning, sequencing and expression of wild-type and mutant receptor proteins. EMBO J 5:2513-2522.

Dorio D, Viau V, Meaney MJ (1993) The role of the medial prefrontal cortex (cingulate gyrus) in the regulation of hypothalamic-pituitary-adrenal responses to stress. J Neurosci 13:3839-3847.

Dutriez-Casteloot I, Bernet F, Dedieu JF, Croix D, Laborie C, Montel V, Lesage J, Beauvillain JC, Dupouy JP (1999) Hypothalamic-pituitaryadrenocortical and gonadal axes and sympathoadrenal activity of adult male rats prenatally exposed to morphine. Neurosci Lett 263:1-4.

Fabre V, Beaufour C, Evrard A, Rioux A, Hanoun N, Lesch KP, Murphy D,
Lanfumey L, Hamon M, Martres M (2000) Altered expression and functions of serotonin $5-\mathrm{HT}_{1 \mathrm{~A}}$ and $5-\mathrm{HT}_{1 \mathrm{~B}}$ receptors in knock-out mice lacking the 5-HT transporter. Eur J Neurosci 12:2299-2310.

Feldman S, Weidenfeld J (1999) Glucocorticoid receptor antagonists in the hippocampus modify the negative feedback following neural stimuli. Brain Res 821:33-37.

Fletcher A, Forster EA, Bill DJ, Brown G, Cliffe IA, Hartley JE, Jones DE, McLenachan A, Stanhope KJ, Critchley DJP, Childs KJ, Middlefell VC, Lanfumey L, Corradetti R, Laporte AM, Gozlan H, Hamon M, Dourish CT (1996) Electrophysiological, biochemical, neurohormonal and behavioural studies with WAY-100635, a potent, selective, and silent 5- $\mathrm{HT}_{1 \mathrm{~A}}$ receptor antagonist. Behav Brain Res 73:337-353.

Franklin KB, Paxinos G (1997) The mouse brain in stereotaxic coordinates. Toronto: Academic.

Froger N, Gardier AM, Moratalla R, Alberti I, Lena I, Boni C, De Felipe C, Rupniak NMJ, Hunt SP, Jacquot C, Hamon M, Lanfumey L (2001) 5-Hydroxytryptamine (5-HT) ${ }_{1 \mathrm{~A}}$ autoreceptor adaptive changes in substance $\mathrm{P}$ (neurokinin 1) receptor knock-out mice mimic antidepressantinduced desensitization. J Neurosci 21:8188-8197.

Haj-Dahmane S, Hamon M, Lanfumey L (1991) $\mathrm{K}^{+}$channel and 5-hydroxytryptamine ${ }_{1 \mathrm{~A}}$ autoreceptor interactions in the rat dorsal raphe nucleus: an in vitro electrophysiological study. Neuroscience 41:495-505.

Hamon M (1997) The main features of central 5- $\mathrm{HT}_{1 \mathrm{~A}}$ receptors. In: Serotoninergic neurons and 5-HT receptors in the CNS. Handbook of experimental pharmacology (Baumgarten HG, Göthert M, eds), pp 239-268. Berlin: Springer.

Hensler JG (2002) Differential regulation of 5- $\mathrm{HT}_{1 \mathrm{~A}}$ receptor-G protein interactions in brain following chronic antidepressant administration. Neuropsychopharmacology 26:565-573.

Héry M, Semont A, Fache MP, Faudon M, Héry F (2000) The effects of serotonin on glucocorticoid receptor binding in rat raphe nuclei and hippocampal cells in culture. J Neurochem 74:406-413.

Holsboer F, Barden N (1996) Antidepressants and hypothalamic-pituitaryadrenocortical regulation. Endocr Rev 17:187-205.

Johren O, Flugge G, Fuchs E (1994) Hippocampal glucocorticoid receptor expression in the tree shrew: regulation by psychosocial conflict. Cell Mol Neurobiol 14:281-296.

Kendler KS, Gardner CO, Prescott CA (2002) Toward a comprehensive developmental model for major depression in women. Am J Psychiatry 159:1133-1145.

Kennett GA, Chaouloff F, Marcou M, Curzon G (1986) Female rats are more vulnerable than male in animal model of depression: the possible role of serotonin. Brain Res 382:416-421.

Kitayama I, Cintra A, Janson A, Fuxe K, Agnati LF, Eneroth P, Aronsson M, Härfstrand A, Steinbusch HWM, Visser TJ, Goldstein M, Vale W, Gustafsson JA (1989) Chronic immobilization stress: evidence for decreases of 5-hydroxytryptamine immunoreactivity and for increases of glucocorticoid receptor immunoreactivity in various brain regions of the male rat. J Neural Transm 77:93-130.

Kitraki E, Karandrea D, Kittas C (1999) Long-lasting effects of stress on glucocorticoid receptor gene expression in the rat brain. Neuroendocrinology 69:331-338.

Laaris N, Haj-Dahmane S, Hamon M, Lanfumey L (1995) Glucocorticoid receptor-mediated inhibition by corticosterone of $5-\mathrm{HT}_{1 \mathrm{~A}}$ autoreceptor functioning in the rat dorsal raphe nucleus. Neuropharmacology 34:1201-1210.

Laaris N, Le Poul E, Laporte AM, Hamon M, Lanfumey L (1999) Differential effects of stress on presynaptic and postsynaptic 5-hydroxytryptamine- ${ }_{1 \mathrm{~A}}$ receptors in the rat brain: an in vitro electrophysiological study. Neuroscience 91:947-958.

Lanfumey L, Pardon MC, Laaris N, Hanoun N, Joubert C, Cohen-Salmon C (1999) $5-\mathrm{HT}_{1 \mathrm{~A}}$ autoreceptor desensitization by chronic ultramild stress in mice. NeuroReport 10:3369-3374.

Linthorst ACE, Flachskamm C, Barden N, Holsboer F, Reul JM (2000) Glucocorticoid receptor impairment alters CNS responses to a psychological stressor: an in vivo microdialysis study in transgenic mice. Eur J Neurosci 12:283-291.

Lowry OH, Rosebrough NJ, Farr ML, Randall RJ (1951) Protein measurement with the Folin phenol reagent. J Biol Chem 193:265-275.

Magarinos AM, Somoza G, De Nicola AF (1987) Glucocorticoid negative feedback and glucocorticoid receptors after hippocampectomy in rats. Horm Metab Res 19:105-109. 
Makino S, Smith MA, Gold PW (1995) Increased expression of corticotropin-releasing hormone and vasopressin messenger ribonucleic acid (mRNA) in the hypothalamic paraventricular nucleus during repeated stress: association with reduction in glucocorticoid receptor mRNA levels. Endocrinology 139:3299-3309.

McPherson GA (1985) Analysis of radioligand binding experiments. A collection of computer programs for the IBM PC. J Pharmacol Methods 14:213-228.

Mizoguchi K, Yuzurihara M, Ishige A, Sasaki H, Chui DH, Tabira T (2001) Chronic stress differentially regulates glucocorticoid negative feedback. Psychoneuroendocrinology 26:443-459.

Mizoguchi K, Ishige A, Aburada M, Tabira T (2003) Chronic stress attenuates glucocorticoid negative feedback: involvement of the prefrontal cortex and the hippocampus. Neuroscience 119:887-897.

Moreau JL, Jenck F, Martin JR, Mortas P, Haefely WE (1992) Antidepressant treatment prevents chronic unpredictable mild stress-induced anhedonia as assessed by ventral tegmentum self-stimulation behavior in rats. Eur Neuropsychopharmacol 2:43-49.

Muscat R, Papp M, Willner P (1992) Reversal of stress-induced anhedonia by the atypical antidepressants, fluoxetine and maprotiline. Psychopharmacology (Berl) 109:433-438.

Pardon MC, Pérez-Diaz F, Joubert C, Cohen-Salmon C (2000) Influence of chronic ultramild stress procedure on decision-making in mice. J Psychiatry Neurosci 25:167-177.

Pariante CM, Miller AH (2001) Glucocorticoid receptors in major depression: relevance to pathophysiology and treatment. Biol Psychiatry 49:391-404.
Pejchal T, Foley MA, Kosofsky BE, Waeber C (2002) Chronic fluoxetine treatment selectively uncouples raphe $5-\mathrm{HT}_{1 \mathrm{~A}}$ receptors as measured by $\left[\gamma^{-35}\right.$ S]-GTP-S autoradiography. Br J Pharmacol 135:1115-1122.

Pepin MC, Pothier F, Barden N (1992) Impaired type II glucocorticoidreceptor function in mice bearing antisense RNA transgene. Nature 355:725-728.

Post RM (1992) Transduction of psychosocial stress into the neurobiology of recurrent affective disorder. Am J Psychiatry 149:999-1010.

Stec I, Barden N, Reul JM, Holsboer F (1994) Dexamethasone nonsuppression in transgenic mice expressing antisense RNA to the glucocorticoid receptor. J Psychiatr Res 28:1-5.

VanderMaelen CP, Aghajanian GK (1983) Electrophysiological and pharmacological characterization of serotonergic dorsal raphe neurons recorded extracellularly and intracellularly in rat brain slices. Brain Res 289:109-119.

Webster MJ, Knable MB, O’Grady J, Orthmann J, Weickert CS (2002) Regional specificity of brain glucocorticoid receptor mRNA alterations in subjects with schizophrenia and mood disorders. Mol Psychiatry 7:985-994.

Willner P (1997) Validity, reliability and utility of the chronic mild stress model of depression: a 10-years review and evaluation. Psychopharmacology (Berl) 134:319-329.

Willner P, Towell A, Sampson D, Sophokleous S, Muscat R (1987) Reduction of sucrose preference by chronic unpredictable mild stress and its restoration by a tricyclic antidepressant. Psychopharmacology (Berl) 93: $358-364$. 